\title{
South African Social Science and the Azanian Philosophical Tradition Anjuli Webster
}

Abstract: This article discusses the contemporary history of South African social science in relation to the Azanian Philosophical Tradition. ${ }^{1}$ It is addressed directly to white scholars, urging introspection with regard to the ethical question of epistemic justice in relation to the evolution of the social sciences in conqueror South Africa. I consider the establishment of the professional social sciences at South African universities in the early twentieth century as a central part of the epistemic project of conqueror South Africa. In contrast, the Azanian Philosophical Tradition is rooted in African philosophy and articulated in resistance against the injustice of conquest and colonialism in southern Africa since the seventeenth century. It understands conquest as the fundamental historical antagonism shaping the philosophical, political, and material problem of 'South Africa'. The tradition is silenced by and exceeds the political and epistemic strictures of the settler colonial nation state and social science.

Keywords: Azanian Philosophical Tradition, conquest, intellectual history, justice, settler colonialism, South Africa

Conquest is not reducible to force alone. Its subsistence depends on the production of an epistemic and symbolic order and power over the representation of history. The paradox of conquest, according to Yves Winter, is that it contains vectors of both disruption and order - it interrupts and suspends an existing political and legal order through a foundational violence, while simultaneously 
establishing a new order. This is possible only by supressing the historical fact of its own foundation as well as its animating principles. In other words, conquest is successful as it disappears (Winter 2012). This negation requires symbolic production in order to make the conqueror appear legitimate or 'ancient', in Machiavellian terms (Machiavelli and Wootton 1995). The foundational violence of conquest must be sutured over and tucked away; the conqueror acquiring authority, if not through love or fear, by the construction of a 'fictional memory' which dispenses with the need for legitimate and just political lineage.

The conquest of southern Africa in the unjust wars of colonisation depended on both military and epistemic violence. The conqueror eliminated, enslaved, and dispossessed indigenous peoples. Thereafter, the conqueror silenced the foundational violence of conquest, constructing a fictional memory of peaceful and benevolent arrival and interaction as the foundation of the settler colonial project. A fictional memory is necessarily precarious, however. It can be called into question by those who remember the foundational historical injustice of colonial conquest and who maintain that the conqueror and the conqueror's posterity were and are present in southern Africa unjustly. Mogobe Ramose shows that prescription is unknown in African law - 'an injustice that endures in the historic memory of the injured is never erased merely because of the passage of time'(Ramose 2001:7). According to the ubuntu understanding of law, which is present in historic memory and in the rules of behaviour in the everyday flow of life but subordinated to the supreme law of South Africa, the 1996 constitution, conquest is an outstanding historical injustice.

The insistence that colonial conquest in southern Africa is an outstanding historical injustice is central to the philosophical and ethical project of the Azanian Philosophical Tradition. According to Ndumiso Dladla, 'Azania' was first used as a political claim against the nominal and political hegemony of 'South Africa' by the PanAfricanist Congress (PAC) in 1959 (Dladla 2018: 3). The name 'Azania' dissents against the historical and philosophical problem of the 1910 Union of South Africa, representing the union of the two settler populations and projects, 'Boer and Briton' against the indigenous conquered people. According to the PAC's vision, Azania described the vision of an African polity not bounded by 
colonial forms of sovereignty, nation, law, or justice, as 'the ends to which Africanist ideology and liberation philosophy were aimed'. Dladla outlines the following features of Azanian philosophy:

1. The insistence by Azanians that the objective of the liberation struggle was the recovery of sovereign title to territory (rather than the mere attainment of civil and political rights).

2. The insistence that the title to territory itself belongs exclusively to the indigenous people conquered in the unjust wars of colonisation.

3. The rejection of multiracialism. This includes incredulity to the tenability of non-racialism as a means and upholding it only as an end achievable only once the title to territory had been restored to the indigenous conquered people.

4. The recognition of 'South Africa' as a polity and idea inextricably bound to the will of the conqueror and requiring state succession by a liberated polity with a restored relationship and continuity with the rest of the African continent. This is against a political history of South Africa having constructed its identity as distinctly European and bearing no cultural resemblance and relationship with 'the rest of the continent' (Dladla 2018: 3).

In this article, I argue that South African social science is a central mechanism of conqueror South Africa, that it silences the outstanding historical injustice of conquest, and that it is at variance with the Azanian Philosophical Tradition. I begin by mapping the establishment of social science departments at South African universities in the early twentieth century. This includes the establishment of anthropology and Bantu Studies departments at the University of Cape Town and the University of the Witwatersrand, and the work and movement of figures such as Alfred Reginald Radcliffe-Brown and Winifred Hoernle. The article focuses largely on anthropology. However, where necessary and appropriate, the discussion considers figures and spheres related to the social sciences more broadly, as well as some of the transnational networks connecting them. While anthropology was the foremost science deployed in colonies during the colonial era, it was epistemically consistent with other social sciences 
including political science, psychology, sociology, and economics. As Archie Mafeje has argued, 'if anthropology is a child of earlier imperialism, political science is a child of modern imperialism' (1976: 320). There are fundamental continuities between early twentieth century and contemporary social science in South Africa. Here I trace the convergences between these moments, concentrating on the historical instances in which social science and white supremacy were politically and epistemically entangled. I then reflect on the deceits which silence the mutability of conquest in social scientific discourse.

Moreover, I read the contemporary history of social science in South Africa against the central claims of the Azanian Philosophical Tradition previously outlined. A primary difference between the Azanian Philosophical Tradition and the white settler tradition is that the former remembers the history and contemporary reality of conquest, while the latter depends on its silencing. Save for a relatively small group of scholars reckoning with the continuities and significance of conquest in the present, many of whom are contributing to this special issue, conquest is not understood as a fundamental historical and political problem in the mainstream South African academy. ${ }^{2}$ I hope to push back against this silence, particularly as it resounds through contemporary social science departments in South Africa.

One of the central myths contributing to the silencing of conquest in South Africa is the idea that 1994 constituted a rupture in South African history, marking the shift from a colonial past to a constitutional present. Dladla challenges this myth, arguing that the 1996 constitution is in fact a historiographical paradigm not only legally but also epistemically silencing conquest (2018). The fictional memory silencing the foundational violence of conquest is accepted and reproduced in academic and normative discourse by those who benefit from its edifice, namely the posterity of the conqueror. This is largely achieved through the exceptionalisation of the violence and injustice of the apartheid era and the uncritical celebration of 1994 as a fundamental break with the past of conquest and settler colonialism in South Africa. However, so long as there are those who remember and understand the 'double injustice of conquest in an unjust war and the denial of the humanity of the conquered' in Africa (Ramose 2001) the negation of conquest's 
animating principle is not a fait accompli. It is a continuous production; it requires work.

I am indebted to Archie Mafeje's work on the history and sociology of knowledge of anthropology and the social sciences in South Africa (Mafeje 1997, 1998). By arguing that anthropology was incompatible with the political project of independent Africa, Mafeje intervened in debates on anthropology in Africa in a way that reflected and echoed the political and ethical motivations of the Azanian Philosophical Tradition. Thabang Dladla has argued that Mafeje's work constituted a 'distinct practice of African philosophy' in its endogenous and liberatory praxis (Dladla 2017). Mafeje's work has largely been branded as polemical in what Bongani Nyoka has termed the 'politicisation of Mafeje' by the white academy in South Africa (Nyoka 2012). This has facilitated an easy dismissal of the intellectual and ethical implications of his work. Through its continued objectification of Black alterity in the present, South African social science silences the fundamental historical antagonism of the conquest of the indigenous people in the unjust wars of colonisation, which continues to structure the political, legal, and epistemic landscapes of the 'new' South Africa.

\section{Consolidating the Professional Social Sciences in South Africa}

This section discusses the advent and consolidation of the professional social sciences at two South African universities during the Union Era: the University of Cape Town and the University of the Witwatersrand. The discussion spotlights two key figures: anthropologists Alfred Reginald Radcliffe-Brown and Agnes Winifred Hoernle. Both Radcliffe-Brown and Hoernle were instrumental in inaugurating a set of institutional, intellectual, and educational networks consolidating the professional social sciences in South Africa during this time. Put together, their educational backgrounds, research and travel circuits, and institutional placements and connections span the globe, their trajectories constituting threads of a broader network of 'global whiteness' (Willoughby-Herard 2015). Each figure also played an important role in articulating new conceptions and theories of 'the native', of social and political 
organisation, and of the role of colonial administration and governance in managing the 'problems' of their present.

Two paradigms came to an end in the first decades of the twentieth century - the geographical expansion of Western colonialism, and the epistemology of evolutionism. According to Patrick Wolfe, the 'triumphalism' of the expansion of the colonial frontier 'shifted to a diffident posture, offering indirect rule and fostering local autonomy'. Correspondingly, the 'anthropological narrative shifted from an all-encompassing developmental hierarchy to a plurality of relativized and self-sustaining sociocultural isolates' (Wolfe 1999: 43). Jack Stauder traces the shift in anthropological theory as related to imperial concerns with appropriate methods of colonial rule as follows:

But if nineteenth-century ethnology was eminently suitable as an intellectual justification for colonial expansion, it was not at all well suited to the succeeding era of colonial consolidation and exploitation. Populations of Africans, once pacified, needed to be administered. Ideas about African culture and society which were grossly unreal or distorted were of no help in this second stage of colonialism; in fact, lack of proper understanding of Africans might well stand in the way of achievement of the British colonial goal of ruling with a minimum of trouble and cost and a maximum of stability and profit. (Stauder 1980: 322)

In the 1920s, anthropological theory shifted in step with changes in the form of imperial rule in Africa. Anthropologists adopted increasingly positivist and functionalist approaches to studying/ constructing political and social communities in southern Africa. According to Mafeje, positivism and its variant, functionalism, were key exports of Britain and France - the leading imperial powers of Europe in the early twentieth century:

The powerful distinction positivism sought to institute between useful (positive) and useless (metaphysical) forms of knowledge was not an accident in vain. ... Instrumental and empirical knowledge was at a premium, as only through it could nature be subdued ever increasingly and the processes of accumulation ever more heightened. (Mafeje 1976: 314)

By the mid-twentieth century, the rise in colonial developmentalism led to an increasing demand for social science research. Colonial social science in the form of sociology, psychology, economics, 
geography, demography, and history were mobilised in the British, French, and Belgian empires (Steinmetz 2017). Wolfe outlines the historical relationship between anthropology, psychology, and sociology as follows:

For most of the century, anthropology and psychology were indistinguishable, as is evident in their shared propensity for skull-measuring. Since both were emerging from a common humanist discourse that embraced individuals and the species alike, the basis for their demarcation is obvious. It concerned scope rather than epistemology - where anthropology became xenographic and collectivist, psychology developed the autographic and individualistic applications of the same narrative, whilst sociology developed the autographic and collectivist ones (the fourth possibility - combining xenography and individualism was to remain beyond institutional imagining). (Wolfe 1999: 151)

Social science disciplines may have produced different 'objects' of study - the Other as primitive and collectivist, the Same as advanced/civilised and individualist. However, the objects of study were coherent within a Eurocentric Humanist conception of the world and consistent within a racist Hegelian teleological conception of World History as a process of civilising evolution, in which the Other is represented as inferior, backward, irrational, and less than fully human.

The establishment of the professional social sciences in South African universities was an affair of global whiteness (WilloughbyHerard 2015). In 1921, following a transnational correspondence between British anthropologist A. C. Haddon, General Jan Smuts, and Sir J. C. Beattie, principal of the University of Cape Town, Alfred Reginald Radcliffe-Brown was appointed to the first chair of social anthropology at the university, and on the African continent (Schapera 1990). The necessity for such an appointment had been recognised in the British commonwealth and the South African scientific community since the first years of the twentieth century. The South African Association for the Advancement of Science, founded in 1902, recognised 'Anthropology and Ethnography' as areas of research concern. By 1907, Henri Junod, Sir Leander Starr Jameson of the Jameson raid, and the Royal Anthropological Institute of England all advocated for the establishment of an 'Ethnographical Bureau'(ibid.: 2). It was only after the consolidation of the Union of South Africa as a British dominion that institutional 
and financial networks, motivation, and impetus aligned to formally establish a 'School of African Life and Languages'.

The founding of university departments in the colony shaped intellectual developments in the metropole and across the empire. The establishment of the School of African Life and Languages at UCT in 1922, followed by the establishment of the Bantu Studies Department at the University of the Witwatersrand in 1923 in turn shaped the meteoric rise of British structural functionalism and the so-called Golden Age of ethnographic monographs across southern Africa.

White scholars were mobile across the global spheres of empire. Their mobility between geographical locations within empires, as well as the transposability of their methods, theories, and intellectual projects more broadly are representative of the reach of social science as a field of study to support administrative integration in the late colonial period. The biographies of several colonial intellectuals circulating between South Africa, Britain, Australia, and the United States in the 1920s help make sense of the foundational years of professional social science in South Africa. Shortly after taking up the post of professor of social anthropology, RadcliffeBrown offered the following account of the importance of 'Bantu sociology' in the South African colonial context:

In Africa, more perhaps than in any other part of the world, social anthropology is a subject not of merely scientific or academic interest, but of immense practical importance. The one great problem on which the future welfare of South Africa depends is that of finding some social and political system in which the natives and the whites may live together without conflict. (Radcliff-Brown cited in Stauder 1980: 324-325)

Radcliffe-Brown emphasised that the establishment and organisation of the department at UCT had been organised around the 'practical importance' of anthropology, thus conceived. In his formulation of the practical value of anthropology in the colonies, we see the work that social science does in making colonial conquest invisible. Radcliffe-Brown deployed a positivist and future-oriented register, representing anthropology as a scientific endeavour which would provide practical solutions to solve existing social and political problems and conflict in South Africa. While the conflict 
is understood to be racial in character, its history is left shrouded in mystery.

Radcliffe-Brown silences the origins of the twentieth century 'problem' of South Africa as conquest, enslavement, and land theft. In doing so, he reproduces the fictional memory of conqueror South Africa. He assumes the existence of white people and the settler colonial project in South Africa as unproblematic. Indeed, he implies that the 'white race' has a right to exist and develop their 'civilisation' without the threat of undue disturbance of stability by indigenous peoples:

In this country [South Africa] we are faced with a problem of immense difficult and great complexity. It is the need of finding some way in which two very different races, with very different forms of civilisation, may live together in one society, politically, economically and morally in close contact, without the loss to the white race of those things in its civilisation that are of greatest value, and without that increasing unrest and disturbance that seem to threaten us as the inevitable result of the absence of stability and unity in any society. (ibid.: 327 )

Conquest, enslavement, theft, and violence are silenced and replaced by a mythological civilisational difference. The conqueror appears ancient, and the fictional memory embeds itself more deeply. Confirming anthropology's tendency towards positivist functionalism and cultural relativism, Radcliffe-Brown posits anthropological research as the solution to an existing social and political problem, representing the discipline as a legitimate and dependable method through which to conceive of a more efficient and less troublesome colonial system. Radcliffe-Brown's support of applied anthropology reinforced the extension of this functionalist approach into broader political and legal structures of colonial rule and governance. He strongly believed that the scientific knowledge produced by anthropologists must be practically applied by colonial administrators and legislators, a position on applied anthropology which was later taken up more broadly by social anthropologists throughout the British Empire (Stauder 1980: 325). Radcliffe-Brown resigned in 1925 and left South Africa to take up the newly established chair of social anthropology at the University of Sydney. In the following decades he taught anthropology across the globe, in Chicago, Oxford, and Alexandria. He eventually returned to South Africa in 
the early 1950 s to teach at Rhodes University. In 1953, he gave the South African Institute of Race Relations' Hoernle Memorial Lecture. In it, he addressed the problem of colonial conquest in South Africa more directly. His critique of segregation and the political and ethical implications of conquest is of interest to the argument of this article:

To talk of letting the Native peoples of South Africa develop along their own lines was nonsense - their own traditional system had been hacked to pieces and not much of it could be reconstructed. ... Developments in Africa were part of a world process, which began in 1450 with the overflow from Europe to different parts of the world, which were occupied by migration, exploration or conquest. The first result of conquest or migration was the integration of different peoples into a 'composite society': the fate of the component peoples in such a society was different in various regions. In Tasmania, the original aborigines disappeared, and in South Africa the Bushman was exterminated. But it was possible for the invaders and conquered to settle down and create a society in which they combine in unity. (Radcliff-Brown cited in Gordon 1990: 29)

In the foregoing quote, there is a curious slippage or assumed synonymy between 'conquest' and 'migration'. They are understood as natural developments of a 'world process' initiated by the 'overflow' of Europe from 1450 onwards. While Radcliffe-Brown acknowledges conquest, and even uses the term 'exterminate' to describe the butchery of indigenous people at the Cape (vs. the euphemistic 'disappearance' of Australian aborigines in Tasmania), ${ }^{3}$ conquest is not understood as a foundational and unjust violence, which must be addressed through restitution and reparations. Rather, the outcome of the conquest of the indigenous people in the unjust wars of colonisation is taken for granted, and the colonial situation built on the foundation of conquest is represented as a legitimate political and legal system. This yields the absurd last sentence: 'But it was possible for the invaders and conquered to settle down and create a society in which they combine in unity'.

The Bantu Studies Department was established at the University of the Witwatersrand in 1923, with the financial backing of the Native Recruiting Corporation and the Witwatersrand Native Labour Association, subdivisions of the Witwatersrand Chamber 
of Mines (Hammond-Tooke 1997: 34). Winifred Hoernle, a student of Radcliffe-Brown, was appointed as the department's ethnographic specialist, and Clement Doke as Bantu linguist. Hoernle, the 'mother' of South African social anthropology grew up and was educated in South Africa in the late nineteenth and early twentieth centuries. In 1903 she registered to complete her bachelors at the then South African College. Between 1908 and 1912 she completed her studies in psychology and anthropology in Europe, studying at Cambridge, Leipzig, and Bonn Universities, and attending lectures at the Sorbonne in Paris (Bank 2016). According to Andrew Bank, her 'list of teachers reads like a roll-call of the founding fathers of the social sciences'. These figures included A. C. Haddon, W. H. R. Rivers, James Frazer, Radcliffe-Brown, Charles S. Myers, Wilhelm Wundt, Oswald Kulpe, and Emile Durkheim (ibid.: 23). Her list of students also reads like a list of the founding settlers of South African structural functionalist anthropology, including Hilda Kuper, Monica Wilson, Eileen Jensen Krige, and Max Gluckman.

The advent of social anthropology at UCT and Wits in the 1920s, and the development of other social science disciplines was deeply interpolated in the development of native administration during the Union period. In the 1930s there was a push from within white liberal institutions, such as the South African Institute of Race Relations, to strengthen the social sciences in universities across South Africa. This came in direct response to the publication of the Carnegie Commission Report on the Poor White Problem in 1933. In her study of the commission, Tiffany Willoughby-Herard argues that the interconnected histories of global racial politics, segregationist philanthropy, and white nationalism rediscovered the white poor to 'suture over racial regimes' and 'prop up antiblack governance' (Willoughby-Herard 2015: xiv). White poorness was thus constructed as a way in which to extend technologies of anti-blackness. The champions of poor whites sought to consolidate 'forced labor, racial oppression, colonial conditions, and capitalist exploitation' 'through domestic and global knowledge projects' 'which incorporated black people through empire building' (ibid.: 1-2).

The rise of the social sciences in reaction to the crisis initiated by the Poor White Commission is significant for our understanding of the philosophical underpinnings of social science praxis in South 
Africa. The idea that there was an urgent necessity of applying the 'scientific method' to 'social problems' in South Africa united settler scholars at both English and Afrikaans universities. Links were established between English liberal universities and, for example, Dr Hendrik Verwoerd based at Stellenbosch University, materialising what has been called 'a league of nations for racial imperialism'. While there were complexities and tensions in the broader political economic milieu of white South Africa, in the broad sense the social sciences in South Africa were raised in the furnace of the 'shared aspiration to white supremacy that united the sentiments and political ideologies of Afrikaner and British South Africans'. ${ }^{4}$

Social science networks spread out far beyond exchanges between the settler colonial government and university enclaves. They included more publicly oriented institutions such as the Joint Councils and the South African Institute of Race Relations, and stretched beyond the geographical boundaries of settler colonial South Africa. The supposedly non-partisan and objective framework of social scientific research depended not only on intellectual and financial, but on personal connections across the Atlantic including friendships between white scholars, researchers and philanthropists, which facilitated the circulation of racist ideas, the reception of these ideas as 'expertise', and the financing of extensive antiblack research and educational projects based on these ideas.

The consistency between the formal social sciences and global settler colonialism is not surprising. What requires further consideration is the conceptual underpinnings of this moment which survives in the present. The methods and theories of the social sciences were generated and shaped through the settler colonial project but have since been perceived as independent of that project and as objective ways to study and think about the world. In part, the exceptionalisation of apartheid in South African historiography has obfuscated the origins of the consolidation of settler racism and white supremacy through the social sciences in the early twentieth century. This historical revisionism and silencing are integral parts of what Charles Mills has termed epistemologies of white ignorance. For Mills, racial liberalism is a 'cultivated amnesia, a set of constructed deafnesses and blindnesses' (Mills 2007). Through 
these epistemologies, historical truth and justice become the casualties of science.

In this section, I have discussed the advent and consolidation of the professional social sciences at two South African universities during the Union Era, focusing on the role played by two figures: Alfred Reginald Radcliffe-Brown and Agnes Winifred Hoernle. I plotted some of the connections and networks that framed shifts in social science in the early twentieth century, focusing on the ways in which these were spliced within the political and intellectual unification of the settler colonial project in South Africa. In the next section, I offer some reflections on the methodological and theoretical afterlives of this moment.

\section{Disciplinary Decadence and the Objectification of Knowledge}

In his discussion of anthropology and the colonial encounter, Talal Asad considers how shifts in global politics shaped the way in which anthropology and the bourgeois social sciences comprehended the world. Social anthropology emerged in tandem with the colonial era, and its 'efforts were devoted to a description and analysis - carried out by Europeans, for a European audience - of non-European societies dominated by European power'. During and following the Second World War, new imperial drives increased interest in African and Asiatic dependencies and colonies. 'The plans for post-war economic and social development in these areas generated under pressure of war-time experiences included big schemes of research in the natural and social sciences' (Asad 1973). The social sciences underwent major crises when faced with the rupture of the Independence era:

Anthropology, which hitherto had treated 'tribal' societies as static or in 'equilibrium', found itself having to explain a number of phenomena which had not been anticipated by its theory. 'Social change', which became a fad in the late fifties and early sixties, was an ex post facto operation which was made even clumsier by the ahistoricism of its sponsors. Their 'diachronic' method juxtaposed awkwardly bounded 'tribal' structures with the fluidity of an adjunct, called 'urban'. (Mafeje 1976) 
In the postcolonial period, African scholars such as Archie Mafeje, Ifi Amadiume, and Talal Asad understood that social scientific knowledge was 'acquired and used most readily by those with the greatest capacity for exploitation'. For Asad, the continuity of anthropology following these changes depended on 'the kind of commonsense world that the typical anthropologist still shares, and knows he shares, with those whom he primarily addresses' (Asad 1973: 14-16). The continuation of white supremacy following the independence era continues to furnish the West with constructed knowledge about the so-called Third World, generating a circular 'universal understanding' which affirms their position of power and domination over that world: 'It is because the powerful who support research expect the kind of understanding which will ultimately confirm them in their world that anthropology has not very easily turned to the production of radically subversive forms of understanding' (ibid.: 17).

While anthropology lays claim to a diffuse relativism through the various 'local' places and people it studies, it remains incorporated within the singularity of Western social scientific knowledge. To use Mafeje's terms, the 'ontology of social sciences thought categories' are products of and consistent with the colonial enterprise in South Africa and have been unable to move beyond their inculpation within this history and philosophical anthropology (Majefe 1976). Lewis Gordon has argued that the 'formulation of knowledge in the singular already situates the question in a framework that is alien to times before the emergence of European modernity and its age of global domination, for the disparate modes of producing knowledge and notions of knowledge were so many that knowledges would be a more appropriate designation' (Gordon 2014: 84). The 'problem status' of indigenous people the world over has been produced through dominant organisations of knowledge, which are taken to be legitimate and universal: 'In effect, being perfect, the systems that produced their condition resist blame for any injustice or contradiction that may be avowed by such people. They become extraneous to those systems' functions in spite of having already been generated by them' (ibid.: 84).

White settlers resist blame for any injustice avowed by the indigenous people conquered in the unjust wars of colonisation by distancing themselves from the historical process and continuity of 
conquest. Social science contributes to this evasion of blame by distancing itself from this history as well. Social scientific method focuses on the local alterity produced through empire and colonialism, claiming to understand the 'problem' in the present, while silencing its own position within the broader structural and historical antagonism. In this deceit, both the positionality of the social scientist and the historical process which has produced its object recede into a murky background, another piece of fictional memory. It is a deceit which is apparent in the work of both RadcliffeBrown and Hoernle previously discussed, and which surfaces in contemporary South African social science as well, through the very philosophical problem of 'South Africa' itself.

Gordon warns us against the dangers of disciplinary decadence. He defines decadence as an

inward path of disciplinary solitude.... This is the phenomenon of turning away from living thought, which engages reality and recognises its own limitations, to a deontologised or absolute conception of disciplinary life. The discipline becomes, in solipsistic fashion, the world. And in that world, the main concern is the proper administering of its rules, regulations, or, as Fanon argued, (self-devouring) methods. Becoming 'right' is simply a matter of applying, as fetish, the method correctly. (ibid.: 86 )

Anthropology focuses on the various alterities that white supremacy produces, concentrating on the local and the particular of the 'problem people', at times adopting ethnographic fundamentalism and often at the expense of including a theorisation of race. According to Asad, the colonial power structure 'made possible the kind of human intimacy on which anthropological fieldwork is based but ensured that that intimacy should be one-sided and provisional' (Asad 1973: 17). It was in this context that the method of ethnography was developed and from which it has been unable to escape. The one-sided provisionality of ethnography has continued through what Mafeje has termed the continued racial alterity of anthropology's objects of study, as an effect of the global rationality of white supremacy.

The possibility condition for the advent of the social sciences was European imperialism and colonialism. However, social science has since been conceived as independent of that project through 
what George Steinmetz has called 'disciplinary anamnesis', or the process of forgetting the colonial entanglements of social science disciplines (Steinmetz 2017: 602). These entanglements are not simply historical or pragmatic; they are also epistemic. We should not be decadent in heeding Gordon's warning. Rather, we should seek to uncover 'the world' that social science has produced and which it claims to be able to understand and reveal. It was not simply the methods of the social sciences that were generated and shaped through imperial and colonial global processes but 'the world' itself. A singular universal world legible to the ontology of social science's thought categories (Mafeje 1976: 318), which in turn reproduces its past, present, and possible futures and silences the traditions of struggle and resistance against it. It is to this silencing that I turn in the next section.

\section{Silencing the Azanian Philosophical Tradition}

In the previous sections, I outlined the historical consolidation of the professional social sciences as part of the unification of settler colonial South Africa and discussed the commonsense singular world which social science reproduces through the deceit of disciplinary amnesia. In this section, I discuss the ways in which this amnesia silences the Azanian Philosophical Tradition (APT). Michel-Rolph Trouillot has outlined four moments of historical production in which silencing can take place. The fourth moment he considers, after the moments of fact creation, fact assembly, and fact retrieval, is the moment of retrospective significance, or the 'presence in the past' (Trouillot 1995: 26, 141). For Trouillot, time is 'not mere chronological continuity' but a 'range of disjointed moments, practices, and symbols that thread the historical relations between events and narrative'. The question of historical authenticity is then located in the present, as it represents the past. Authentic scholarship in the present must establish a relation to the past that it represents, not as a way of separating itself from that past, but of being honest about the fluidity between the past and the present (Trouillot 1995: 146-149).

The Azanian Philosophical Tradition threatens the apparent legitimacy of white social science in South Africa by threatening 
to reveal its consistency with the violence of conquest. By calling attention to the problem of 'South Africa' itself, the APT highlights the historical injustice upon which the present rests, and points to the complicity of white social science in maintaining the fiction that South Africa is a free and just society. Joel Modiri has argued that 'the political question of how we should read the constitutional present in South Africa is intimately tied to the epistemic injustice of the virtually complete silencing of African and black intellectual and political perspectives, voices and realities in legal theory and related disciplines' (Modiri 2018: 302). This silencing is a mode of survival. For, if the Azanian political perspective were to be genuinely engaged, the foundations, form, and hegemony of white South African social science would necessarily collapse.

In order to maintain the unethical fiction that South Africa is a free and just society and that white social scientific praxis is ethically sound and politically unproblematic, contemporary white social science scholarship engages in two main modes of silencing. First, it silences the continuity of white supremacy in the present. This is achieved through two interconnected dishonesties: (1) the exceptionalisation of apartheid in the history of white supremacy in South Africa, coupled with an acceptance of its overthrow in 1994; and (2) the construction of an apparent difference between settler intellectual and political traditions, and the scapegoating of the Afrikaner tradition as the most racist and conservative of the two. For example, in a recent article, Isak Niehaus reproduces this distinction in a discussion of the history of anthropology in South Africa at the dawn of apartheid, comparing the figures of A. R. Radcliffe-Brown and Bronislaw Malinowski. Niehaus represents Radcliffe-Brown as a more progressive interlocutor in South African anthropology compared with Malinowski. Radcliffe-Brown developed affinities with more liberal-minded settler anthropologists in the English language tradition including Winifred Hoernle, Monica Wilson, Hilda Kuper, Isaac Schapera, who develop an 'anthropological critique of apartheid'. Whereas Malinowski was sympathetic to the intellectual tradition of anthropology that would develop into apartheid-era Volkekunde, and shared affinity with anthropologists in the supposedly more conservative Afrikaner tradition, including Jack and Eileen Krige. In constructing this divide, Niehaus sets up apartheid as a moral category which separates Radcliffe-Brown 
and Malinowski and their various South African interlocutors. This divide silences the continuities between the policies, legal and epistemic structure of the Union and apartheid periods, as well as the work which figures like Radcliffe-Brown and Hoernle did to consolidate settler colonialism and racial segregation in South Africa (Niehaus 2016: 113-114).

Despite Steve Biko's warning four decades ago that whosoever opposed apartheid was not necessarily an ally of the Black Consciousness Movement, the liberal English tradition is today still constructed and reproduced as the more progressive alternative to the conservative Afrikaner intellectual and political tradition. While there may have been disagreement and tension between these two traditions, an uncritical focus on their differences obfuscates their unity in consolidating settler colonialism, and the philosophical and political problem of 'South Africa'.

The second mode of silencing that contemporary white social science engages in is the silencing of traditions of black intellectual resistance to white supremacy. There is little to no serious engagement by white scholars with the intellectual and political traditions, including the Black Radical Tradition (BRT) (Robinson 1983) and the Azanian Philosophical Tradition, that have resisted and theorised white supremacy, conquest, enslavement, and colonialism from below for the last one hundred years at least. One clear example of the disregard for the conceptual interventions of the BRT and the APT is the ubiquity of class analysis as the primary analytic through which South African society is comprehended and written by the white left.

Marxism entered the white South African academy from the late 1960s and 1970s largely through the work of white scholars such as Shula Marks and influenced by the left-leaning academic orthodoxy in Western Europe. Its rapid uptake in the South African academy can be understood in part as a response to the epistemological rupture and crisis for white supremacy posed by the Black Consciousness Movement. Shireen Ally has offered an excellent account of the historical and intellectual stakes of Marxism's rise to influence and authority in the realm of sociology at Wits University. The development of oppositional Marxist sociology in the 1970s is commonly explained as 'a product of the freedom from state repression and constraints: that Marxism emerged in the 1970s out of the 
removal of constraints on intellectuals to pursue a critical sociology, and as an expression of their rejection of power' (Ally 2005: 71). Ally offers a critique of this conception of power, arguing that intellectual projects which position themselves as critical of the state may still be implicated in power. This was the case with Marxist sociology's 'reactionary disengagement' from the challenge to white radicalism posed by Black Consciousness. According to Ally, 'Marxist oppositional intellectualism did not emerge out of the vacuum of social power that resulted from the removal of various constraints during this time. Instead, its genesis was securely located in a configuration of power, one in which its reformulation of the relationship between race and class represented a politics of survival and self-defence' (ibid.: 82).

Social science's method of self-defence continued after 1994. The particular form of popular 'post-apartheid' class-focused analysis took speculative form almost concurrently with the transition to democracy. As early as 1995, journalist Allister Sparks outlined its dimensions as he speculated on the future of South Africa after the end of apartheid:

Here was my glimpse into the future; of a new class stratification gradually beginning to overlay South Africa's old racial strata, never completely eliminating the old divisions but blurring them and adding a different dimension. At the top of this new class structure will be a predominantly white economic aristocracy, the present captains of industry who will be joined in time by a few black entrepreneurs. Then there will be a large multiracial middle class, followed by a working class of artisans, miners, and factory workers, a predominantly black proletariat with a significant white component (unskilled whites will lose the privileged status apartheid gave them). The working class will also rank as part of the economic elite, since its members will be people with jobs surrounded by a sea of unemployed. . . Still, the stresses of conflicting class interests will assert themselves over time, the different factions will respond to these in different ways, and when the towering figure of Nelson Mandela is no longer there as a binding force, fragmentation seems inevitable. (Sparks 1995: 185-186)

Sparks's account reveals the epistemic groundwork on which the rise of a discourse of class differentiation has come to dominate and silence the continuation of the structure of white supremacy in 'post-apartheid' South Africa. Despite the fact that Marxian analysis 
fell out of favour following the end of the Cold War, and the rise of post-structuralism, the afterlives of Marxian and class-based analysis are evident in the recent publication of a number of monographs and collected editions which understand capitalism and class differentiation as the fundamental historical antagonisms structuring South African contemporary history. ${ }^{5}$ Not only do these studies silence the injustice of conquest in contemporary South Africa, they also affirm the Western canon's hegemony over 'theory' by reproducing Marxist understandings of political and economic society.

Recently, the possibility of a decolonised tradition of social science has been raised from within the South African academy. Hylton White has argued that 'decolonising ethnography positions the indigenous not as an essence but as a standpoint of critique'. White thinks with the possibility that the condition of estrangement, the practice at the heart of ethnography, can be a productive starting point for critical analysis. He maintains that the method of ethnographic estrangement still offers important ways to challenge 'existing conceptions of humanity and of the social forms that mediate its nature' and argues that anthropology has much to learn from the 'decolonising thought' expressed in the past few years from the underbelly of the South African academy (White 2019). Whether this moment of possibility is at odds with the Azanian Philosophical Tradition is perhaps still to be seen. Nevertheless, we need to think carefully about the historical position from which estrangement is conceived and the politics and ethics of the will to estrangement without restitution and reparations.

\section{Conclusion}

In this article I have demonstrated how social science silences the outstanding historical injustice of conquest in South Africa. South Africa emerged out of the crucible of conquest, now sutured over and made unthinkable through the fictional memory of a singular Western-centric rationality. South African social science and the Azanian Philosophical Tradition emerged on different sides of the historical development of white supremacy in southern Africa. One emerged as an imperial technology of knowledge production 
rooted in the Eurocentric rationality of conquest, domination, and exploitation. The other as a tradition of resistance to the oppression and injustice of conquest and colonialism rooted in African philosophy. Contemporary social science hides its origin and complicity in conquest and colonialism in order to maintain the appearance of political and epistemic legitimacy. Through its continued objectification of Black alterity in the present, South African social science silences the fundamental historical antagonism of the conquest of the indigenous people in the unjust wars of colonisation. In doing so, social science functions ideologically to shore up white supremacy by failing to ground its enquiry explicitly in relation to the fundamental historical antagonism of conquest.

In contemporary South Africa, the pretence to neutral scientific knowledge skirts the contradictions and inequalities inherent in conquest society. This pretence is part of the symbolic production of fictional memory. The pretence also discounts the reality of the widespread and systematically sanctioned death of the indigenous conquered people in South Africa. By paying attention to class difference at the expense of a theory of race and historical power, South African social science silences the problems of outstanding historical justice, restitution, and reparations for colonial conquest and settler colonialism. It is these outstanding injustices that the Azanian Philosophical Tradition insists on understanding and addressing as foundational antagonisms which continue to structure the political, legal, and epistemic landscape of the 'new' South Africa. Moreover, the Azanian Philosophical Tradition threatens the present order of South Africa. It defies the political and epistemic strictures of the settler colonial present. In Michel-Rolph Trouillot's terms, the Azanian Philosophical Tradition is unthinkable - it cannot be conceived as a plausible alternative because it 'defies the terms under which the questions were phrased' (Trouillot 1995: 82). This is because it exceeds the terms of order of 'South Africa' and risks the possibility of a new world and the end of white supremacy. Through the emancipatory possibilities contained within its fugitive unthinkability the Azanian Philosophical Tradition offers a path towards the abolition of South Africa and the realisation of Azania. 


\section{Acknowledgements}

I wrote this article in part during a Johannesburg Institute of Advanced Study writing residency. The research was funded by the National Research Foundation and the Patrick and Margaret Flanagan Foundation.

Anjuli Webster is currently a Woodruff Fellow in the African History $\mathrm{PhD}$ programme at Emory University. Her research explores empire, law, and sovereignty in southeastern Africa. Specifically, she is interested in histories of dispossession, enclosure, and border formation between the British and Portuguese Empires along the Indian Ocean littoral in the nineteenth century. E-mail: awebst4@emory.edu

\section{Notes}

1. In this article I take seriously Steve Biko's call for white people in South Africa to address racism in their own communities rather than attempt to participate in Black struggles, as has so often been the predilection of white liberals in the past. As such, I address this article directly to white scholars in South Africa and more broadly and insist that we grapple more seriously with the indictment of the history and present of social science research in South Africa.

2. See Ramose, M. B., 2001, 'An African Perspective on Justice and Race'; Ramose, M. B., 2002, 'I Conquer, Therefore I Am the Sovereign: Reflections upon Sovereignty, Constitutionalism, and Democracy in Zimbabwe and South Africa', in P. H Coetzee and A. P. H Roux (eds), Philosophy from Africa: A Text With Readings. Oxford: Oxford University Press, 463-500; Dladla, N., 2017, Here Is a Table: A Philosophical Essay on the History of Race in South Africa (Pretoria: Ears Publishing); Dladla, N., 2018, 'The Liberation of History and the End of South Africa: Some Notes towards an Azanian Historiography in Africa, South'; Modiri, J., 2018, 'Conquest and Constitutionalism: First Thoughts on an Alternative Jurisprudence', South African Journal on Human Rights 34 (3): 300-325; Webster, A., 2018, 'On Conquest and Anthropology in South Africa', South African Journal of Human Rights 34 (3): 398-414.

3. Also of interest here is the representation of the Khoi-San as the only indigenous people present in southern Africa during the unjust wars of colonial conquest, a mischievous representation which has since been appropriated to construct "empty land' arguments. For a critique of this, see Marks, S., 1980, 'South Africa: "The Myth of the Empty Land"', History Today 30 (1): 7-12.

4. For a discussion of the sometimes competing economic interests of the Afrikaner volk and British Capital in South Africa, see O'Meara, D., 1983, Volkskapitalisme: Class, Capital and Ideology in the Development of Afrikaner Nationalism, 1934-1948 (Cambridge: Cambridge University Press); Willoughby-Heard, T., 2015, Waste of a White Skin: The Carnegie Corporation and the Racial Logic of White Vulnerability (Oakland: University of California Press). 
5. Southall, R., 2016, The New Black Middle Class in South Africa (Auckland Park: Jacana); Satgar, V., 2015, Capitalism's Crises: Class Struggles in South African and the World (Johannesburg: Wits University Press); Beresford, A., 2016, South Africa's Political Crisis: Unfinished Liberation and Fractured Class Struggle (London: Palgrave Macmillan); Melber, H., 2017, The Rise of Africa's Middle Class: Myths, Realities and Critical Engagements (Johannesburg: Wits University Press).

\section{References}

Ally, S. 2005. 'Oppositional Intellectualism as Reflection, Not Rejection, of Power: Wits Sociology, 1975-1989', Transformation: Critical Perspectives on Southern Africa 59: 66-97. doi: 10.1353/trn.2005.0045

Asad, T. 1973. Anthropology and the Colonial Encounter. London: Ithaca Press.

Bank, A. 2016. Pioneers of the Field: South Africa's Women Anthropologists. Johannesburg: Wits University Press.

Beresford, A. 2016. South Africa's Political Crisis: Unfinished Liberation and Fractured Class Struggle. London: Palgrave Macmillan.

Dladla, N. 2017. Here Is a Table: A Philosophical Essay on the History of Race in South Africa Pretoria: Ears Publishing

Dladla, N. 2018. 'The Liberation of History and the End of South Africa: Some Notes towards an Azanian Historiography in Africa, South', South African Journal of Human Rights 34 (3): 415-440. Doi: 10.1080/02587203.2018.1550940

Dladla, T. 2017. 'Archie Mafeje and the Question of African Philosophy: A Liberatory Discourse', South African Journal of Philosophy 36: 350-361. Doi: 10.1080/02580136.2017.1301161

Gordon, L. R. 2014. 'Disciplinary Decadence and the Decolonisation of Knowledge', Africa Development XXXIX(1): 81-92.

Gordon, R. 1990. 'Early social anthropology in South Africa', African Studies 49(1): 15-48.

Hammond-Tooke, W. D. 1997. Imperfect Interpreters: South Africa's Anthropologists 1920-1990. Johannesburg: Wits University Press.

Machiavelli, N. and D. Wootton. 1995. The Prince. Indianapolis: Hackett Publishing Company.

Mafeje, A. 1976. 'The Problem of Anthropology in Historical Perspective: An Inquiry into the Growth of Social Sciences', Canadian Journal of African Studies 2 (10): 307-333. Doi: 10.1080/00083968.1976.10803758

Mafeje, A. 1997. 'Who Are the Makers and Objects of Anthropology? A Critical Comment on Sally Falk Moore's "Anthropology and Africa", African Sociological Review 1 (1): 1-15.

Mafeje, A. 1998. 'Anthropology and Independent Africans: Suicide or End of an Era?', African Sociological Review 2 (1): 1-43.

Marks, S. 1980. 'South Africa: "The Myth of the Empty Land", History Today 30 (1): 7-12. 
Melber, H. 2017. The Rise of Africa's Middle Class: Myths, Realities and Critical Engagements. Johannesburg: Wits University Press.

Mills, C. W. 2007. 'White Ignorance'. In S. Sullivan and N. Tuana (eds), Race and Epistemologies of Ignorance. Albany: Suny Press, 11-38.

Modiri, J. 2018. 'Conquest and Constitutionalism: First Thoughts on an Alternative Jurisprudence', South African Journal on Human Rights 34 (3): 300-325. Doi: 10.1080/02587203.2018.1550939

Niehaus, I. 2016. 'Anthropology at the Dawn of Apartheid: Radcliffe-Brown and Malinowski's South African engagements, 1919-1934', Focaal 76 (3). doi:10.3167/fcl.2017.770109

Nyoka, B. 2012. 'Mafeje and "Authentic Interlocutors": An Appraisal of His Epistemology', African Sociological Review 16 (1): 4-18.

O’Meara, D. 1983. Volkskapitalisme: Class, Capital and Ideology in the Development of Afrikaner Nationalism, 1934-1948. Cambridge: Cambridge University Press.

Ramose, M. B. 2001. 'An African Perspective on Justice and Race', Polylog 3. https://them.polylog.org/3/frm-en.htm

Ramose, M. B. 2002. 'I Conquer, Therefore I Am the Sovereign: Reflections upon Sovereignty, Constitutionalism, and Democracy in Zimbabwe and South Africa'. In P. H Coetzee and A. P. J. Roux (eds), Philosophy from Africa: A Text With Readings. Oxford: Oxford University Press, 463-500.

Robinson, C. J. 1983. Black Marxism: The Making of the Black Radical Tradition. Chapel Hill: University of North Carolina Press.

Satgar, V. 2015. Capitalism's Crises: Class Struggles in South African and the World (Johannesburg: Wits University Press).

Schapera, I. 1990. 'The Appointment of Radcliffe Brown to the Chair of Social Anthropology at the Univrsity of Cape Town', African Studies 49 (1): 1-13.

Southall, R. 2016. The New Black Middle Class in South Africa. Auckland Park: Jacana.

Sparks, A. 1995. Tomorrow Is Another Country: The Inside Story of South Africa's Negotiated Settlement. Johannesburg: Jonathan Ball Publishers.

Stauder, J. 1980. 'Great Britain: Functionalism Abroad: A Theory in Question'. In S. Diamong (ed), Anthropology: Ancestors and Heirs. The Hague: Mouton Publishers, 317-344.

Steinmetz, G. 2017. 'Sociology and Colonialism in the British and French Empires, 1945-1965', The Journal of Modern History 89: 601-648. doi: $10.1086 / 692991$

Trouillot, M. 1995. Silencing the Past: Power and the Production of History. Boston: Beacon Press.

Webster, A. 2018. 'On Conquest and Anthropology in South Africa', South African Journal of Human Rights 34 (3): 398-414.

White, H. 2019. 'What Is Anthropology That Decolonising Scholarship Should Be Mindful of It?', Anthropology Southern Africa 42: 149-160. doi:10.1080/ 23323256.2019.1574210 
Willoughby-Herard, T. 2015. Waste of a White Skin: The Carnegie Corporation and the Racial Logic of White Vulnerability. Oakland: University of California Press.

Winter, Y. 2012. 'Conquest', Political Concepts. https://www.politicalconcepts. org/conquest-winter/\#ref21

Wolfe, P. 1999. Settler Colonialism and the Transformation of Anthropology: The Politics and Poetics of an Ethnographic Event. London: Cassell. 